\title{
Offshoring and Occupational Wages: Some empirical evidence
}

\author{
Arne Bigsten \\ Dick Durevall \\ Farzana Munshi
}

August 2008

ISSN 1403-2473 (print)

ISSN 1403-2465 (online)

SCHOOL OF BUSINESS, ECONOMICS AND LAW, UNIVERSITY OF GOTHENBURG

Department of Economics

Visiting adress Vasagatan 1,

Postal adress P.O.Box 640, SE 40530 Göteborg, Sweden

Phone + 46 (0)31 7860000 


\title{
Offshoring and Occupational Wages: Some Empirical Evidence
}

\author{
By \\ Arne Bigsten, Dick Durevall, and Farzana Munshi* \\ Department of Economics \\ School of Business, Economics and Law \\ University of Gothenburg, Box 640, SE-40530 Gothenburg, Sweden
}

\begin{abstract}
Offshoring has changed the pattern of international competition; labor in specific occupations rather than whole firms and sectors are now facing competition. Accordingly, wages in offshorable occupations are affected in new ways. In this paper we investigate the effects of offshoring of electronically traded services on relative occupational wages in 13 countries in the 1990-2003 period. Our findings show that increased exports of IT-related services lead to higher relative wages in offshorable occupations, whereas increased imports of such service reduce them. There is also some evidence that the impact of offshoring on relative wages is larger the lower the level GDP per capita.
\end{abstract}

Keywords: Offshoring, globalization, occupational wages, service trade.

JEL codes: F15, F16, J31.

\footnotetext{
* We would like to thank Måns Söderbom and Karolina Ekholm as well as seminar participants at the Department of Economics, University of Gothenburg, for very useful comments. Financial assistance from the Wallander-Hedelius foundation is gratefully acknowledged.
} 


\section{Introduction}

Offshore outsourcing of electronically traded services from high-wage to low-wage countries began in earnest in the early 1990s. Increased trade and capital mobility together with improvements in information and telecommunication technology have accelerated the process, and more and more IT-related services are being offshored (Amiti and Wei, 2005; Welsum and Vickery, 2005). This new wave of globalization brings new challenges; both high-skilled workers (e.g., software engineers, researchers, and analysts) and low-skilled workers (e.g., call center operators and data entry clerks) in high-wage developed countries now face competition from their counterparts in low-wage developing countries. Competition and specialization increase productivity in general, and therefore, the prosperity of the participating countries. But does offshore outsourcing benefit everyone?

One of the reasons behind the apprehension in the public debate and in the media over offshore outsourcing of electronically traded services (henceforth offshoring) in developed countries is the fear of job loss and downward pressure on real wages in certain high-skilled occupations, where these countries have had a comparative advantage for a long time (Amiti and Wei, 2005; Coe, 2008). Many of these jobs have been outsourced to developing countries where the job (task) can be done at much lower cost and delivered electronically at negligible cost. This has increased the demand for labor in these occupations in developing countries, resulting in increases in their wages.

By offshoring routine tasks to low-wage developing countries, producers in highwage developed countries can specialize in complex tasks in which they have comparative advantages, and hence expand and create more such jobs. Overall real incomes of the origin (developed) country are likely to increase as a result of cheaper imports from the 
destination (developing) country. The idea is similar to the standard gains from trade story; trade (offshoring) reduces cost of labor if the various segments in the production chain are allocated according to comparative advantages. Although some workers will of course suffer from temporary dislocation due to the trade, full employment can be attained in the long run through market adjustments. Therefore, also this trade can bring benefits to all participating countries.

Ireland is a good example in this context. In the early 1990s it attracted a lot of US offshored services, since wages were competitive. However, as wages rose in Ireland, the US and other outsourcing countries started to look for new destinations. For example, China, the Philippines, Malaysia, and India in particular, have become attractive offshoring locations. However, by now wages in some offshored occupations are increasing rapidly in India as well. Interestingly, the search-engine company Like.com recently decided to close its Indian center, since it was not cost-effective any more; wage levels of software engineers in Bangalore and California had become too similar. ${ }^{1}$

Research on the impact of globalization or market integration on labor markets, factor prices, production patterns, and welfare has mainly been based on models with complete goods produced in one location. With increased offshoring, trade in specific tasks or intermediate goods has come to play a very significant role, which also affects factor price movements. To date little research has been done on the impact of offshoring on income distribution in the participating countries, although some studies have analyzed the effects of offshoring on labor demand (Ekholm and Hakkala, 2006), on employment

\footnotetext{
${ }^{1}$ This information is accessed online at http://influencepeddler.blogspot.com
} 
(Schöller, 2006), and on relative wages of skilled to unskilled workers (Grossman and Rossi-Hansberg, 2006b).

In this paper we undertake an exploratory analysis of available cross-country data to see if we can identify any systematic effects of the offshoring of IT-related services on relative wages. Since we are not testing a full model, we have to be cautious with causal interpretations. However, we still believe that we are able to find some interesting correlations that may inform the debate.

The regression analysis is done on a panel of 13 countries in Europe and Asia for the 1990-2003 period. To our knowledge, this is the first study that exploits the crosssection variations across countries to try to understand the potential effects of offshoring on relative wages in offshorable and non-offshorable occupations. We find that increases in exports of IT-related services are associated with increases in relative wages of offshorable occupations, and that there is some, but weaker, evidence of a reverse effect for increases in imports. This suggests that increased relative demand for these occupations boosts their relative wages. We also find that the effect is largest in developing countries, and that it declines as GDP per capita increases

The remainder of the paper is organized as follows: Section 2 describes offshorable jobs and the countries involved in offshoring, Section 3 discusses some relevant literature on offshoring and the debate around it, Section 4 describes the data and the variables used in the empirical analysis, Section 5 presents the results, and Section 6 concludes the paper. 


\section{Offshoring}

As a background to the analysis in this paper, we begin by briefly describing the characteristics of offshorable jobs and the countries to which these jobs are offshored.

\subsection{Offshorable jobs}

This paper analyzes the offshoring of Mode 1 services under the General Agreement on Trade in Services (GATS). These services are traded electronically and often over long distances. Welsum and Vickery (2005) identify a set of occupations which potentially would be affected by offshoring. According to their classification, offshorable jobs are occupations that embody high explicit information but do not require face-to-face contact (codified knowledge), and most importantly, information and communication technology is intensively used in the process of production as well as in trade of the service. More generally, "routine” tasks (Levy and Murname, 2004) and "codifiable” tasks (Leamer and Storper, 2001) are most suitable for offshoring. Welsum and Vickery (2005) predict that around $20 \%$ of total employment in OECD countries is potentially offshorable, while Bardhan and Kroll (2003) predict that about 11\% of total US employment is.

Offshoring can involve both high-skill and low-skill jobs. Examples of workers include call center operators (Friedman, 2004), radiologists (Pollak, 2003), software programmers (Thurm, 2004), and people preparing tax forms (Robertson et al., 2005). Nonoffshorable occupations are those that require face-to-face personal contact and where the services cannot be delivered electronically. Most personal services are non-offshorable; e.g., taxi drivers, child care workers, nurses, barbers, automobile mechanics, cooks, as well as jobs in construction and mining. Hardly any physician jobs, except in radiology, are 
offshorable, since they require face-to-face personal contact. Some government services may not require face-to-face contact, but are still generally not offshorable for political reasons.

With technological progress, more and more jobs are becoming offshorable. Blinder (2006) and Jensen and Kletzer (2005) predict that the number of offshorable jobs in the US will soon exceed the number of manufacturing jobs. For example, services in wholesale and retail trade are good candidates for offshoring due to the steady increase in Internet retailing. In the health sector, laboratory tests are suitable for offshoring. Jobs in financial services as well as attorneys writing routine contracts can also be offshored. However, most jobs in the tourist sector cannot be, except for reservation clerks. Furthermore, researchrelated and innovative jobs use substantial information technology but are not offshorable. Leamer and Storper (2001) use the term “double-edged geography of the Internet age” to explain how the Internet is spreading out routine tasks while at the same time concentrating (agglomerating) research and innovative activities.

\subsection{Offshoring countries}

The Global Services Location Index (GSLI), developed by A.T. Kearney (a leading international management consulting firm), provides a ranking of offshore locations according to their attractiveness to investors. It is created by evaluating 40 countries based 
on three criteria: financial attractiveness, skills and availability of people, and business environment. $^{2}$

In the GSLI list, the top six countries are Asian: India, China, Malaysia, the Philippines, Singapore, and Thailand. Central and Eastern Europe is attractive to many nonEnglish speaking high-wage European countries due to language skills and geographical proximity. Skills in European languages other than English are uncommon in low-wage Asian countries.

There is a common view that the US and other English-speaking countries will cope better with the challenges of offshoring than non-English Europe, since English skills are a necessary requirement for delivering services electronically (Blinder, 2005). However, using the data on service imports of accounting and other back-office operations, which are indicators of actual offshoring, Amiti and Wei (2005) point out that four out of five top outsourcers of business services in 2002 were non-English speaking countries: Germany, Japan, the Netherlands, and Italy.

\section{Literature Review}

The classical models of trade focused on the exchange of finished goods. Since communication costs were high, it was reasonable to assume that splitting-up of production processes was only done in close proximity. Technological improvements and the decline of communication costs have made more and more goods and services tradable, which has led to changes in the pattern of comparative advantages.

\footnotetext{
${ }^{2}$ Financial attractiveness includes compensation levels, infrastructure, and tax and regulatory costs. People skills and availability is based on remote services sector experiences and quality ratings, labor force availability, education and language, and attrition risk. Business environment includes infrastructure, cultural exposure, and security of intellectual property. For details on these sub-categories and the 40 individual metrics on which they are based, see Appendix of A.T.Kearney (2005).
} 
The splitting up of production processes has made high-wage developed countries outsource various labor-intensive tasks of production to low-wage countries. ${ }^{3}$ It has been found in several empirical studies that outsourcing has increased wage inequality in developed countries (Feenstra and Hanson, 1999; Hijzen, 2007), and it has been argued that it leads to a tendency towards factor price equalization (Deardorff, 2001).

Rapid improvements in telecommunication technology since the 1990s have made the cost of trading services small, which has increased the tradability of services. Blinder (2006) calls this the “Third Industrial Revolution.” The concurrent opening-up of large economies like China, India, and Russia has speeded up of this process.

There are several reasons why the emergence of offshoring has been a challenge to the standard theoretical predictions of the impact globalization on skilled and unskilled employment and wages. ${ }^{4}$ First, offshoring involves both high-skill and low-skill occupations. It is therefore difficult for the traditional comparative advantage theory to identify clear “winners” (skilled workers in developed countries) and "losers” (unskilled workers in developed countries) of globalization in terms of skill-level. Second, in addition to trade in complete goods as in standard trade theory, trade in specific tasks or intermediate goods has come to play an increasingly significant role in international factor price movements.

\footnotetext{
${ }^{3}$ Outsourcing, however, is also done domestically.

${ }^{4}$ Following the 2X2 Hecksher-Ohlin intuition, integration in commodity markets induces factor price convergence between developed and developing countries through Stolper-Samuelson effects (Stolper and Samuelson, 1941; Samuelson, 1953). An increased wage inequality is consequently predicted in developed countries.
} 
The changing pattern of global trade caused by offshoring demands new theories, and some have begun to emerge regarding both trade in tasks and trade in final goods. ${ }^{5}$ Grossman and Rossi-Hansberg (2006a) present a simple analytical framework to analyze the effect of offshoring on domestic factor prices. They decompose the effect into three components: a productivity effect, a relative-price effect, and a labor-supply effect. The productivity effect refers to the reduction in production costs derived from increased offshoring. This means that a firm can obtain inputs more cheaply than before and hence become more profitable, which in turn leads to an increase in the demand for labor in offshorable occupations. The relative-price effect refers to the effect of changes in relative goods prices due to offshoring. Reduced prices of goods that use offshorable labor intensively will tend to reduce wages of labor in offshorable occupations in the origin country (the Stolper-Samuelsson prediction). The labor-supply effect is similar to the impact of increased labor supply in an economy, which will generally decrease wages. The effect arises because workers in offshorable occupations are released from their jobs due to offshoring. If the productivity effect dominates the other two, then wages of the workers in offshorable jobs may actually increase. When putting their model to use they find evidence that the combined effect of productivity and labor-supply effects was increased real wages of unskilled US workers in the 1997-2004 period (Grossman and Rossi-Hansberg, 2006b). ${ }^{6}$

To our knowledge, there are no studies investigating the impact of offshoring of ITrelated services on relative wages of offshored occupations. However, some studies (Feenstra and Hanson, 1999; Ekholm and Ulltveit-Moe, 2007) analyze the impact of

\footnotetext{
${ }^{5}$ See Baldwin (2006) for a recent review.

${ }^{6}$ Rodriguez-Clare (2007) uses a similar approach, where the impact of offshoring on average wages is analyzed with three effects: productivity effects, terms of trade effects, and world-efficiency effects.
} 
offshoring on relative wages of skilled workers using the definition of offshoring as import of all intermediate inputs, both material and services. Feenstra and Hanson (1999) find that in the $1979-1990$ period, offshoring was responsible for $17.5 \%-40 \%$ of the increase in the relative wages of non-production US workers. Ekholm and Ulltveit-Moe (2007) develop a general equilibrium model of imperfect competition, where the impact of offshoring on relative wages of skilled workers depends on two opposite forces: vertical specialization and competition. Greater vertical specialization may increase the skill premium and therefore wage inequality in industrialized countries. On the other hand, increased competition may reduce the wage premium and therefore wage inequality in these same countries. The recent fall in the gap between non-production and production workers in US manufacturing may, according to Ekholm and Ulltveit-Moe (2007), be due to the dominance of the second force.

Also, some papers study the impact of offshoring on employment. Schöller (2006) finds that offshoring had a negative impact on manufacturing employment in Germany. However, by analyzing data for several OECD countries for the 1995-2003 period Welsum and Reif (2005) conclude that there was no absolute decline in employment in most countries, although the occupations in question did experience slower employment growth during the period.

\section{Data and Variables}

This section motivates the choice of variables and describes the data used in the empirical analysis. Table 1 reports the descriptive statistics of the main variables used in the analysis. 
Welsum and Vickery (2005) identify some occupations that are potentially affected by offshoring in Europe and other countries using the International Standard Classification of Occupation-1988 (ISCO-88). ${ }^{7}$ The Occupational Wages around the World (OWW) database, ${ }^{8}$ used in our analysis, also follows the ISCO-88 classification. Using this link we end up with wages of 23 offshorable occupations that match the classification of Welsum and Vickery (2005). In order to evaluate the effects of off-shoring on occupational wages, we compare the wages of each of these occupations with an average of 14 non-offshorable occupations for the period 1990-2003 for several countries. This is different from Feenstra and Hanson (1999), Ekholm and Ulltveit-Moe (2007), and Grossman and Rossi-Hansberg (2006b), where relative wages of skilled to unskilled workers are analyzed using data from the US manufacturing sector. A list of offshorable and non-offshorable occupations with the corresponding ISCO code is reported in Table A1 and Table A2 in the Appendix.

Table 1 about here

We focus our analysis on countries ranked by A.T. Kearney’s (2005) Global Services Location Index. Twenty-one countries, developed as well as developing, are classified as the most attractive offshore locations in Europe and Asia. However, due to missing data in the OWW database, only 13 can be included in our analysis. These (in order of rank) are India, China, the Philippines, Singapore, Thailand, the Czech Republic, Slovakia, Poland, Hungary, Romania, the UK, Germany, and Portugal.

\footnotetext{
${ }^{7}$ See Welsum and Vickery (2005) for a detailed methodology on how to select occupations.

${ }^{8}$ Freeman and Oostendorp (2000) created this database by standardizing the ILO October Inquiry data, which is essentially a large country-occupation-time matrix reporting occupational wages for 164 occupations for more than 150 countries in the respective national currencies.
} 
Our variable of interest is the relative wage in offshorable occupations. We construct this variable as the ratio of each offshorable occupational wage to the average wage level of all non-offshorable occupations. An increase in the ratio implies that the offshorable occupational wages increase relative to those in non-offshorable occupations.

It is difficult to measure the extent of offshoring. Only parts of the production processes are offshored, and they are regarded as inputs to produce the final goods. Hence, indirect measures such as imports of services are sometimes used; particularly "computer and information services” and "other business services” from the IMF Balance of Payments database have been used as proxies for the measures (Amiti and Wei, 2005; Schöller, 2006). Data on "computer and information services" is unfortunately not available for many of our countries for the studied time period. We therefore use information on "other business services” (business services for short) only, measured in constant US dollars. The business services are traded electronically and include, among others, accounting jobs, management consulting, legal services, research and development, architectural and engineering services, and other back-office operations (United Nations, 2002). The countries in our sample are both exporters and importers of such services, and hence we use both export and import of business services as measures of offshoring. Real business services exports and imports (in logs) are the main explanatory variables in the model. These can be viewed as indicators of the strength of offshoring.

The attractiveness of a country as an offshoring destination can also be measured by the AT Kearney (2005) Global Services National Index. We use this variable (index) as an alternative to our direct offshoring measure, business services trade. The more attractive locations should export more business services and therefore have higher relative wages 
than less attractive locations. We would expect this variable to have a positive impact on relative wages in offshorable occupations.

The impact of offshoring on wages is likely to vary across occupations and levels of development, and there are large differences in the level of development among the 13 countries in our sample. The current trend of relocation of business services is towards lowwage countries (e.g., India) from high-wage countries (e.g., Germany). This increases the demand for labor involved in outsourcing occupations in India relative to Germany. Moreover, high-wage countries have more integrated labor markets, implying a lower wage differentiation across occupations in those countries. Therefore, we would expect business services exports to increase relative wages the most in countries with relatively low levels of GDP per capita.

Likewise, imports of business services might also have different impacts on relative wages depending on a country’s level of development. High-wage countries are generally increasing the import of business services. If the productivity effect dominates, then increased imports of business services may actually increase relative wages in these countries (see Grossman and Rossi-Hansberg, 2006a; Rodriguez-Clare, 2007), while the effect on relative wages is negative if the relative-price and labor-supply effects dominate.

To control for the size of the economy, and to evaluate differences in impact due to the level of development, we include both the level of real GDP per capita measured in thousands of 2000 PPP dollars and terms where the offshoring variables interact with the level of GDP, in addition to export and import of business services. ${ }^{9}$

\footnotetext{
${ }^{9}$ GDP per capita is purchasing power parity adjusted and in constant 2000 international dollars, which is obtained from the Penn World Table 6.2.
} 


\section{Empirical Analysis}

To investigate the impact of service offshoring on relative occupational wages, various versions of the following model are estimated.

$$
\begin{aligned}
W_{c i t}= & \alpha_{1}+\alpha_{2} X_{c t}+\alpha_{3} M_{c t}+\alpha_{4} L_{c}+\alpha_{5} Y_{c t}+\alpha_{6} X_{c t} Y_{c t}+\alpha_{7} M_{c t} Y_{c t} \\
& +D_{t}+D_{i}+D_{c}+u_{c i t}
\end{aligned}
$$

The subscripts $c, i$, and $t$ are indexes for country, occupation and time, respectively. The dependent variable $W_{\text {cit }}$ is the log of the ratio of wages for each offshorable occupation relative to the country average of non-offshorable occupational wages. $X_{c t}$ and $M_{c t}$ represent the log of real exports and imports of business services respectively, and $L_{c}$ is an index of the attractiveness of a location for offshoring. $Y_{c t}$ denotes log of GDP per capita, and $X_{c t} Y_{c t}$ and $M_{c t} Y_{c t}$ are two interaction variables between exports of business services $(X)$ and log of GDP per capita, and between imports of business services $(M)$ and $\log$ of GDP per capita respectively. $D_{i}$ and $D_{c}$ are occupation and country dummy variables, and $D_{t}$ is a time trend capturing changes in relative wages not due to offshoring. The time trend is included because we expect relatively more rapid productivity growth for offshorable than for non-offshorable occupations, since offshorable occupations are generally assumed to be more high-tech. Finally, $\alpha_{1}$ is the intercept and $u_{c i t}$ is an error term. The standard errors are corrected for clustering within occupations for each country.

The results from the estimated models are presented in Tables 2 and 3. We begin by estimating a simple model; the specification includes both exports and imports of business services and GDP per capita as explanatory variables. The results are reported in Table 2, Column (1). The coefficient of business services exports is positive and highly significant, 
while imports and GDP per capita are insignificant. This suggests that increased exports of business services increase relative wages of offshored occupations, whereas increased imports of business services do not have any impact. In particular, a 1\% increase in exports of business services contributes to a $0.55 \%$ increase in relative wages. Next, the time trend is added, but it is not significant and does not alter the earlier findings as shown in Column (2). This is a general result so we report the rest of the regressions without a time trend.

To control for non-observed occupational effects, the specification in Column (3) adds time-invariant occupational dummies to the first specification. Many of the estimated coefficients for the occupation dummies, and GDP per capita, are statistically significant. The results for exports and imports are similar to those in the previous models, although the size of the coefficient of business services exports is now clearly higher, 0.68 compared 0.55 , and it is significant the $1 \%$ instead of $5 \%$ level.

Next we re-estimate the model in Column (3), replacing business services trade with our alternative measure of offshoring, the attractiveness measure. The results are reported in Column (4). The coefficient of the attractiveness index has the predicted sign and is highly statistically significant. This suggests that the most attractive offshoring locations attract the most outsourcing jobs, which results in higher relative wages in offshorable occupations.

Table 2 about here

Table 3 reports estimations with occupation and country dummies, with and without the interaction variables (Columns (1) and (2)). Adding country dummies, with Romania as 
the omitted country, makes all the business trade variables insignificant; the exports coefficient has even the wrong sign. GDP per capita is now significant at the $1 \%$ level and has a positive sign. Most of the country dummies are significant, and have signs that correspond quite well to our expectations, i.e., the attractiveness measure. In Column (2), which is the most general model, India, Thailand, China and The Philippines and have significant and positive coefficients, Germany, the UK and Hungary have significant and negative coefficients, while the Czech Republic, Slovakia, Poland and Singapore have coefficients that are not significantly different from zero, all compared to Romania. The somewhat surprising finding is Portugal, which has a significant positive coefficient.

Apparently our indicator of offshoring, trade in business services, mainly measures cross-country effects. Hence, an alternative specification is to use the growth rates of exports and imports instead. We thus test if there is a stronger pressure on relative wages in countries where real business exports and imports grow fast than in countries where there is little or no growth, controlling for cross-country differences and GDP per capita. Column (3) in Table 3 reports the specification without interaction terms. The coefficients of both exports and imports of business services are now significant and have the expected signs, i.e., exports raise the relative wage, while imports reduce it. GDP per capita is positive and significant as before. Column (4) shows the results with interaction terms. The coefficient of the interaction term between exports of business services and the log of GDP per capita is negative and significant at the $10 \%$ level, while the interaction term for imports is insignificant, although it has the expected positive sign and the p-value is 0.12 . 
Evaluated at the sample mean of log GDP per capita, the marginal effect of exports reported in Column (4) is 0.098 and highly significant (s.e. 0.0032); a 1\% increase in export growth thus increases relative wages by $0.098 \%$. The marginal effect of import growth is -0.092 (s.e. 0.045 ), significant at the $5 \%$.

Table 3 about here

Overall, the main results make sense and appear to be fairly consistent in all specifications; particularly increased exports of business services contribute to an increase in relative wages of the offshorable occupations at the mean level of log GDP per capita. However, another important result is that the impact varies across country levels of development, as illustrated in Figure 1. It shows the absolute values of the marginal effect for the countries ranked in order of GDP per capita. In the poorest countries we see that the effects are strong, while the effects are clearly smaller in the most developed countries. This is consistent with our initial argument that the impact on relative wages is likely to be higher in thinner and less integrated labor markets than in more developed ones. In sophisticated labor markets, adjustments are smoother, wage gaps across occupations are smaller, and people in different occupations with similar levels of education or skills have more similar wages. Therefore, developed countries can more easily adjust to a change in the demand for offshorable occupations with smaller effects on relative wages.

Figure 1 here 
The negative demand effect in service-importing countries is also counteracted by the productivity effect, which might explain the smaller impact of business service imports. By offshoring relatively inefficient production processes, a firm can reduce unit costs and invest in more complex activities where it has a comparative advantage. Several studies find a positive relation between increased offshoring and productivity (Amiti and Wei, 2006; Mann, 2004). Grossman and Rossi-Hansberg (2006a) show theoretically how increased productivity caused by offshoring can have an increasing effect on the real wages of the offshored occupations in the origin country. Rodriguez-Clare (2007) points out that even if developed countries may experience a downward trend in offshored occupational wages in the short run, positive productivity effects may dominate in the long run, resulting in increased wages.

\section{Concluding remarks}

Rapid improvements in information and communication technology during the last decade have increased tradability of services. Such trade has received a lot of media and political attention recently, especially in developed countries. Although service outsourcing is still at a relatively low level, it is growing with technological improvements. It is therefore of great interest to understand its impact on wages and income distribution.

The empirical findings in this paper are admittedly tentative - addressing the issues at hand in a more satisfactory fashion requires better data. Still, we do believe that our results indicate that increased exports of IT-related services lead to higher relative wages in related offshorable occupations in developing countries, whereas increased imports should have the opposite effect. 
Instead of debating whether offshoring is good or bad, the focus in the more developed countries should primarily be on how much of the increased national income caused by offshoring should be redistributed for re-training and unemployment insurance for the workers whose jobs have been offshored. Interventions to deal with structural change and income distribution problems are probably also important for the maintenance of popular support for a policy of openness (Coe, 2008). In the poorer countries wage differentials are increasing more strongly, while the capacity to intervene to deal with inequities is more limited. Still, one can hardly deplore the fact that skilled jobs are moving there and increasing their overall income level, even if it takes a longer time for the effects to spread to broader segments of the population.

Although the empirical results in this paper are quite strong, the weaknesses of the data must again be acknowledged. The analysis has therefore been forced to use partial measures of offshoring and a limited number of occupational wage data observations. Nonetheless, we do believe that the difference between developing and developed countries with regard to the impact is interesting and significant, and that it should survive a more comprehensive econometric analysis with better data. 


\section{References}

Amiti, M. and Wei, S. (2005), Fear of Service Outsourcing: Is it justified? Economic Policy 20, 308-348.

Amiti, M. and Wei, S. (2006), Service Offshoring and Productivity: Evidence from the US, NBER working paper 11926.

A.T.Kearney (2005), Building the Optimal Global Footprint, http://www.atkearney.com/.

Baldwin, R. (2006), Globalization: The Great Unbundling(s), Working Paper, Economic Council of Finland.

Bardhan, A.D. and Kroll, C. (2003), The New Wave of Outsourcing, Fisher Center Research Reports, University of California, Berkeley.

Blinder, A. S. (2005), Fear of Offshoring, CEPS working paper no 119.

Blinder, A. S. (2006), Offshoring: The Next Industrial Revolution? Foreign Affairs, 85:2, 113-128.

Coe, David T. (2008) “Jobs on Another Shore” Finance and Development 45:1.

Deardorff, A. V. (2001), Fragmentation in simple trade models, North American Journal of Economics and Finance 12, pp 121-137.

Ekholm, K. and Hakkala, K. (2006), The Effect of Offshoring on Labour Demand: Evidence from Sweden, CEPR Discussion Paper 5648.

Ekholm, K. and Ulltveit-Moe, K. H. (2007), A new look at offshoring and inequality: specialization versus competition, CEPR Discussion Paper 6402.

Feenstra, R. C. and Hanson, G. H. (1999), The Impact of Outsourcing and HighTechnology Capital on Wages: Estimates for the United States, 1979-1990, Quarterly Journal of Economics 114, 907-41. 
Freeman, R.B and Oostendorp, R. (2000), Wages around the World: Pay across Occupations and Countries, NBER Working Paper Series 8058.

Friedman, T. (2004), What Goes Around..., The New York Times, Online Edition, February 26.

Grossman, G. M. and Rossi-Hansberg, E. (2006a), Trading Tasks: A Simple Theory of Offshoring, NBER Working Paper Series, 12721.

Grossman, G. M. and Rossi-Hansberg, E. (2006b), The Rise of Offshoring: It's Not Wine for Cloth Anymore, manuscript, Princeton University.

Hijzen, A. (2007), International Outsourcing, Technological Change, and wage Inequality Review of International Economics 15(1), 188-205.

Jensen, J.B. and Kletzer, L.G. (2005), Tradable services: understanding the scope and impact of service offshoring, Institute for International Economics Working Paper 05-9.

Leamer, E. E. and Michael Storper, M. (2001), The Economic Geography of the Internet Age, Journal of International Business Studies, 32:4, 641-665

Levy, F. and Murname, R. (2004), The New Division of Labor, Princeton, NJ: Princeton University Press.

Mann, C. L. (2004), Globalization of IT Services and White Collar Jobs: The Next Wave of Productivity Growth, International Economics Policy Brief, PB03-11.

Pollak, A. (2003), Who’s Reading Your X-Ray? The New York Times, Online Edition, November 16, 
Robertson, J., Stone, D., Niedewanger, L., Grocki, M., Martin, E., and Smith, Ed (2005), Offshore Outsourcing of Tax-Return Preparation, The CPA Journal, Online Publication of New York State Society of CPA, June.

Rodriguez-Clare, A. (2007), Offshoring in a Ricardian World, NBER working paper 13203. Samuelson, P.A (1953), Prices of Factors and Goods in General Equilibrium, Review of Economic Studies, 21, 1-20.

Schöller, D. (2006), Service Offshoring: A Challenge for Employment? Evidence from Germany, University of Hohenheim No. 23/2006.

Stolper, W. and Samuelson, P. A. (1941), Protection and Real Wages, Review of Economic Studies, 9(1), 51-68.

Thurm, S. (2004), Tough Shift-Lesson in India: Not Every Job Translates Overseas, The New York Times, Online Edition, March 3.

United Nations (2002), Manual of Statistics of International Trade in Services, Statistical Papers, Series M No.86.

Welsum, D. and Reif, X. (2005), Potential Offshoring: Evidence from Selected OECD Countries, OECD, Paris.

Welsum, V. D., and Vickery, G. (2005), Potential Offshoring of ICT-Intensive Using Occupations, DSTI Information Economy Working Paper, OECD, Paris. 


\section{Appendix}

Table A1: Offshorable occupations [23].

\begin{tabular}{lcl}
\hline OWW code & ISCO-88 code & Occupations \\
\hline 11 & 2147 & Coalmining engineer \\
14 & 2147 & Petroleum and natural gas engineer \\
46 & $412 / 3 / 4 / 9$ & Office clerk \\
52 & 2146 & Chemical engineer \\
76 & 2143 & Power distribution and transmission engineer \\
77 & $412 / 3 / 4 / 9$ & Office clerk \\
$45 / 91 / 130 / 134 /$ & 4111 & Stenographer-typist in different sectors \\
140 & & \\
94 & 3433 & Book-keeper in retail trade \\
97 & 4222 & Hotel receptionist \\
120 & 4221 & Airline ground receptionist \\
128 & 4223 & Telephone switchboard operator \\
129 & 2411 & Accountant \\
132 & 4114 & Book-keeping machine operator \\
$133 / 138$ & 2132 & Computer programmer in different sectors \\
$135 / 141$ & 4113 & Card- and tape-punching machine operator in different sectors \\
136 & 3412 & Insurance agent \\
142 & $412 / 3 / 4 / 9$ & Office clerk \\
\hline
\end{tabular}


Table A2: Non-offshorable occupations [14].

\begin{tabular}{lcl}
\hline OWW code & ISCO-88 code & Occupation \\
\hline 13 & 9311 & Underground helper in coalmining \\
15 & 3117 & Petroleum and natural gas extraction technician \\
56 & 9322 & Laborer in manufacturing of industrial chemical \\
61 & 2230 & Occupational health nurse \\
81 & 7137 & Building electrician \\
82 & 7136 & Plumber \\
84 & 7141 & Building painter \\
85 & 7122 & Bricklayer \\
98 & 5122 & Cook \\
99 & 5123 & Waiter \\
100 & 9132 & Room attendant or chambermaid \\
111 & 8323 & Motor bus driver \\
114 & 3141 & Ship’s chief engineer \\
118 & 3143 & Air transport pilot \\
\hline
\end{tabular}


Table 1. Descriptive Statistics 1990-2003.

\begin{tabular}{lccc}
\hline Variables & Mean & $\begin{array}{c}\text { Standard } \\
\text { Deviation }\end{array}$ & $\mathrm{N}$ \\
\hline $\begin{array}{l}\text { Log of relative wage (the ratio of wages of } \\
\text { offshorable to non-offshorable occupations) }\end{array}$ & 0.217 & 0.517 & 1606 \\
Log of real exports of business services $^{\mathrm{a}}$ & 5.836 & 2.102 & 1635 \\
Log of real imports of business services $^{\mathrm{a}}$ & 6.324 & 1.902 & 1635 \\
Log (GDP per capita $^{\text {a }} / 1000$ ) & 2.204 & 0.837 & 1650 \\
Index of the attractiveness of a location & 5.361 & 0.625 & 1650 \\
\hline
\end{tabular}

${ }^{a}$ Real exports and imports are in 2000 constant US dollar prices, and real GDP per capita is in thousands of 2000 PPP dollars. 
Table 2: The effects of offshoring on relative occupational wages: 1990-2003.

\begin{tabular}{|c|c|c|c|c|}
\hline \multirow[t]{2}{*}{ Dependent variable } & \multicolumn{4}{|c|}{ Relative wage } \\
\hline & $(1)$ & $(2)$ & (3) & (4) \\
\hline Exports & $0.055^{\mathrm{b}}(0.026)$ & $0.062^{\mathrm{b}}(0.026)$ & $0.068^{\mathrm{a}}(0.017)$ & \\
\hline Imports & $0.037(0.028)$ & $0.026(0.031)$ & $0.019(0.019)$ & \\
\hline GDP per capita & $-0.063(0.061)$ & $0.077(0.068)$ & $-0.090^{c}(0.047)$ & $-0.035(0.036)$ \\
\hline Time trend & & $0.007(0.006)$ & & \\
\hline Location index & & & & $0.309^{\mathrm{a}}(0.061)$ \\
\hline \multicolumn{5}{|l|}{ Occupation dummies } \\
\hline D11 & & & $0.665^{\mathrm{a}}(0.134)$ & $0.726^{\mathrm{a}}(0.119)$ \\
\hline D14 & & & $0.686^{\mathrm{a}}(0.133)$ & $0.738^{\mathrm{a}}(0.121)$ \\
\hline D45 & & & $0.005(0.148)$ & $0.048(0.123)$ \\
\hline D46 & & & $-0.032(0.148)$ & $0.037(0.122)$ \\
\hline D52 & & & $0.613^{\mathrm{a}}(0.157)$ & $0.717^{\mathrm{a}}(0.140)$ \\
\hline D76 & & & $0.634^{\mathrm{a}}(0.156)$ & $0.729 a(0.138)$ \\
\hline D77 & & & $0.218(0.164)$ & $0.321^{\mathrm{b}}(0.137)$ \\
\hline D91 & & & $-0.061(0.158)$ & $0.004(0.139)$ \\
\hline D94 & & & $-0.032(0.159)$ & $0.044(0.143)$ \\
\hline D97 & & & $-0.136(0.152)$ & $-0.022(0.121)$ \\
\hline D120 & & & $0.513^{\mathrm{c}}(0.266)$ & $0.580^{\mathrm{b}}(0.230)$ \\
\hline D128 & & & $0.121(0.163)$ & $0.184(0.136)$ \\
\hline D129 & & & $0.886^{\mathrm{a}}(0.189)$ & $0.929^{\mathrm{a}}(0.167)$ \\
\hline D130 & & & $0.345^{\mathrm{c}}(0.188)$ & $0.383^{\mathrm{b}}(0.153)$ \\
\hline D132 & & & $0.389^{\mathrm{c}}(0.218)$ & $0.448^{\mathrm{b}}(0.194)$ \\
\hline D133 & & & $0.719^{\mathrm{a}}(0.182)$ & $0.789^{\mathrm{a}}(0.156)$ \\
\hline D134 & & & $0.358(0.268)$ & $0.367(0.226)$ \\
\hline D135 & & & $0.217(0.260)$ & $0.219(0.215)$ \\
\hline D136 & & & $0.351^{\mathrm{c}}(0.179)$ & $0.458^{\mathrm{b}}(0.188)$ \\
\hline D138 & & & $0.291(0.187)$ & $0.348^{\mathrm{b}}(0.137)$ \\
\hline D140 & & & $-0.100(0.156)$ & $-0.076(0.118)$ \\
\hline D141 & & & $0.007(0.209)$ & $-0.016(0.167)$ \\
\hline Constant & $-0.192(0.230)$ & $-14.066(10.977)$ & $-0.385^{\mathrm{c}}(0.209)$ & $-1.701^{\mathrm{a}}(0.376)$ \\
\hline Observations & 1591 & 1591 & 1591 & 1606 \\
\hline R-squared & 0.160 & 0.162 & 0.530 & 0.522 \\
\hline
\end{tabular}

Notes: Standard errors, in parentheses, are corrected for clustering. Superscripts a, b, and c denote statistical significance at the $1 \%, 5 \%$, and $10 \%$ level respectively. 
Table 3: The effects of offshoring on relative occupational wages including country dummies

\begin{tabular}{|c|c|c|c|c|}
\hline Dependent variable: Relative wage & $(1)$ & (2) & (3) & $(4)$ \\
\hline Exports & $-0.012(0.023)$ & $-0.008(0.029)$ & & \\
\hline Imports & $0.024(0.031)$ & $-0.006(0.035)$ & & \\
\hline Exports x GDP per capita & & $-0.003(0.002)$ & & \\
\hline Imports x GDP per capita & & $-0.000(0.003)$ & & \\
\hline Growth rate of exports & & & $0.075^{\mathrm{a}}(0.025)$ & $0.110^{\mathrm{a}}(0.037)$ \\
\hline Growth rate of imports & & & $-0.065^{\mathrm{b}}(0.033)$ & $-0.105^{\mathrm{b}}(0.052)$ \\
\hline Growth rate of exports $\times$ GDP per capita & & & & $-0.005^{\mathrm{c}}(0.003)$ \\
\hline Growth rate of imports $\times$ GDP per capita & & & & $0.006(0.004)$ \\
\hline GDP per capita & $0.297^{\mathrm{a}}(0.065)$ & $0.557 \mathrm{a}(0.118)$ & $0.300^{\mathrm{a}}(0.067)$ & $0.293^{\mathrm{a}}(0.067)$ \\
\hline Country dummies & & & & \\
\hline Germany & $-0.553^{\mathrm{a}}(0.140)$ & $-0.901^{\mathrm{a}}(0.170)$ & $-0.600^{\mathrm{a}}(0.123)$ & $-0.590^{\mathrm{a}}(0.122)$ \\
\hline United Kingdom & $-0.088(0.156)$ & $-0.448^{\mathrm{b}}(0.196)$ & $-0.151(0.145)$ & $-0.142(0.144)$ \\
\hline Singapore & $-0.301^{\mathrm{b}}(0.141)$ & $-0.157(0.135)$ & $-0.313^{\mathrm{b}}(0.149)$ & $-0.307^{\mathrm{b}}(0.148)$ \\
\hline Portugal & $0.277^{\mathrm{a}}(0.094)$ & $0.222^{\mathrm{b}}(0.099)$ & $0.277^{\mathrm{b}}(0.108)$ & $0.288^{\mathrm{a}}(0.106)$ \\
\hline Czech & $-0.032(0.084)$ & $-0.060(0.088)$ & $-0.010(0.091)$ & $-0.005(0.091)$ \\
\hline India & $1.124^{\mathrm{a}}(0.156)$ & $1.380^{\mathrm{a}}(0.175)$ & $1.141^{\mathrm{a}}(0.145)$ & $1.134^{\mathrm{a}}(0.146)$ \\
\hline China & $0.346^{\mathrm{a}}(0.132)$ & $0.571^{\mathrm{a}}(0.131)$ & $0.376^{\mathrm{a}}(0.095)$ & $0.374^{\mathrm{a}}(0.095)$ \\
\hline Philippines & $0.398^{\mathrm{a}}(0.119)$ & $0.559^{\mathrm{a}}(0.126)$ & $0.404^{\mathrm{a}}(0.105)$ & $0.404^{\mathrm{a}}(0.105)$ \\
\hline Thailand & $0.731^{\mathrm{a}}(0.108)$ & $0.794^{\mathrm{a}}(0.105)$ & $0.779^{\mathrm{a}}(0.097)$ & $0.780^{\mathrm{a}}(0.097)$ \\
\hline Slovakia & $0.007(0.073)$ & $-0.054(0.080)$ & $0.023(0.080)$ & $0.026(0.079)$ \\
\hline Poland & $-0.084(0.106)$ & $-0.149(0.106)$ & $-0.067(0.071)$ & $-0.062(0.070)$ \\
\hline Hungary & $-0.211^{\mathrm{b}}(0.101)$ & $-0.303^{\mathrm{a}}(0.110)$ & $-0.173^{\mathrm{c}}(0.096)$ & $-0.168 c(0.096)$ \\
\hline Constant & $-0.877^{\mathrm{a}}(0.176)$ & $-1.065^{\mathrm{a}}(0.208)$ & $-0.811^{\mathrm{a}}(0.164)$ & $-0.799 a(0.165)$ \\
\hline Occupation dummies & Yes & Yes & Yes & Yes \\
\hline Observations & 1591 & 1591 & 1426 & 1426 \\
\hline R-squared & 0.711 & $\odot .713$ & 0.715 & 0.716 \\
\hline
\end{tabular}

Notes: Standard errors, in parentheses, are corrected for clustering. Superscripts a, b, and c denote statistical significance at the $1 \%, 5 \%$, and $10 \%$ level respectively. 
Figure 1. Absolute values of marginal effects of increased exports $(+)$ and imports $(-)$ on relative wages by GDP per capita

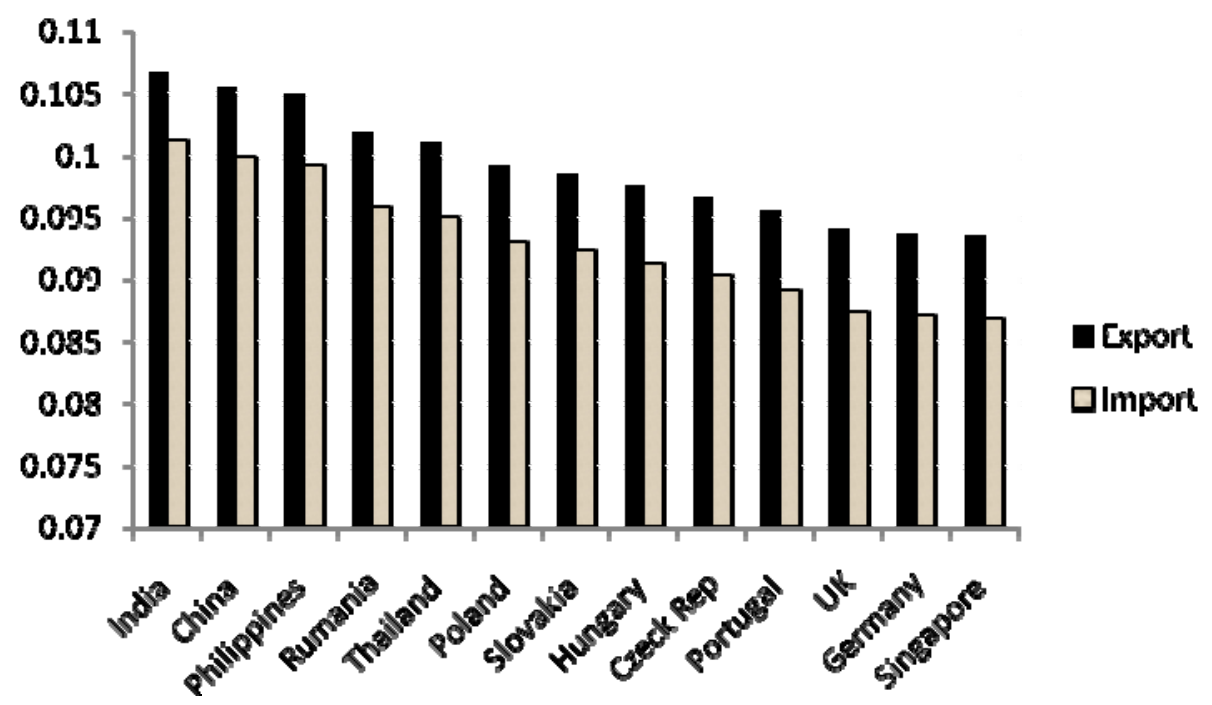

Note: The marginal effects of exports and imports are calculated using the regression coefficients in Table 3, Column (4). The countries are ranked according to average value of the log GDP per capita. 